\title{
Analisis Pola Pembelian Obat di Apotek Sekar Adi Menggunakan Metode Algoritma Apriori Depok
}

\author{
Siti Awaliyah Rachmah Sutomo ${ }^{1}$, Frisma Handayanna ${ }^{2}$ \\ Sekolah Tinggi Manajemen Informatika Nusa Mandiri \\ Jl. Damai No. 8, Warung Jati Barat (Margasatwa), Jakarta Selatan \\ awaliyahrachmahs@gmail.com ${ }^{1}$, frisma.fha@nusamandiri.ac.id ${ }^{2}$
}

\begin{abstract}
By using data mining methods can be processed to obtain information and assist in decision making, the amount of data on sales transactions in each drug purchase can cause a data accumulation and various problems, such as drug stock inventory, and sales transaction data, with Data mining techniques, the behavior of consumers in making transactions of drug purchase patterns can be analyzed, It can be known what drugs are commonly purchased by mostly people, the application of Apriori Algorithm is expected to help in forming a combination of itemset. The process of determining drug purchase patterns can be carried out by applying the Appriori algorithm method, determination of drug purchase patterns can be done by looking at the results of the consumer's tendency to buy drugs based on a combination of 3 itemset. By calculating the Analysis of High Frequency Patterns and the Formation of Association Rules, with a minimum of 30\% support, there is a combination of 3 itemsset namely MOLAGIT PER TAB (M1), VIT C TABLET (V2), and PARACETAMOL 500 MG TABLET (P2) with $33.33 \%$ support results obtained, and with minimum confidence of $65 \%$ there are 6 final association rules.
\end{abstract}

Keywords: Apriori Algorithm, free medicine, and Association Rules

\begin{abstract}
Abstrak
Dengan menggunakan metode data mining dapat di proses untuk mendapatkan informasi dan membantu dalam pengambilan keputusan, banyaknya data pada transaksi penjualan di setiap pembelian obat dapat menimbulkan penumpukan data dan berbagai macam masalah, contohnya seperti persediaan stok obat, dan data transaksi penjualan, dengan teknik data mining bisa di analisis perilaku konsumen dalam melakukan transaksi pola pembelian obat, dapat diketahui obat apa saja yang biasa dibeli oleh kebanyakan masyarakat, penerapan Algoritma Apriori di harapkan dapat membantu dalam membentuk suatu kombinasi itemset. Proses penentuan pola pembelian obat dapat dilakukan dengan menerapkan metode algoritma appriori, penentuan pola pembelian obat dapat dilakukan dengan melihat hasil dari kecenderungan konsumen membeli obat berdasarkan kombinasi 3 itemset. Dengan menghitung Analisis Pola Frekuensi Tinggi dan Pembentukan Aturan Asosiasi, minimal support 30\% terdapat kombinasi 3 itemset yaitu MOLAGIT PER TAB (M1), VIT C TABLET (V2), dan PARACETAMOL 500 MG TABLET (P2) dengan hasil support yang didapat 33,33\%, dan minimal confidence $65 \%$ terdapat 6 final association rules.
\end{abstract}

Kata Kunci: Algoritma Apriori, Obat Bebas, dan Association Rules

\section{PENDAHULUAN}

Kebiasaan masyarakat dalam mengonsumsi obat dikarenakan sebagai salah satu cara untuk penyembuhan dan pencegahan berbagai macam penyakit. Apotek Sekar Adi yang berada di daerah Depok adalah salah satu apotek yang menjual berbagai macam obat dan menerima resep dokter. 
Pengolahan data pada Apotek Sekar Adi masih sangat sederhana, banyaknya data pada transaksi penjualan di setiap pembelian obat dapat menimbulkan penumpukan data dan berbagai macam masalah, salah satu contohnya seperti persediaan stok obat, dan data transaksi penjualan, untuk itu di butuhkan sebuah metode data mining untuk mengolah data tersebut menjadi data yang lebih berguna dan bisa meningkatkan kualitas penjualan.

Dengan menggunakan metode data mining dapat di proses untuk mendapatkan informasi dan membantu dalam pengambilan keputusan, dengan teknik data mining bisa di analisis perilaku konsumen dalam melakukan transaksi pola pembelian obat, data transaksi pembelian obat dapat diolah kembali sehingga bisa menghasilkan suatu pola pembelian obat pada konsumen [1]. Salah satu metode data mining yang di gunakan dalam penelitian ini adalah Algoritma Apriori. Algoritma Apriori termasuk dalam aturan asosiasi (association rules) yaitu untuk menemukan frequent item sets pada sekumpulan data, Algoritma Apriori proses untuk menentukan suatu aturan asosiasi yang dapat memenuhi syarat minimum support dan syarat minimun [2].

Dapat diketahui obat apa saja yang biasa dibeli oleh kebanyakan masyarakat, penerapan Algoritma Apriori di harapkan dapat membantu dalam membentuk suatu kombinasi item, kemudian dilakukan pengujian apakah kombinasi tersebut memenuhi nilai minimun support dan confidence yang merupakan nilai yang telah ditentukan oleh pengguna. Jika telah memenuhi nilai support dan confidence maka hasil tersebut dapat membantu dalam penentuan pola pembelian obat berdasarkan kebiasaan konsumen [4].

\section{METODOLOGI PENELITIAN}

Mengindentifikasi masalah dalam analisis pola pembelian obat pada Apotek Sekar Adi. Adapun metode penelitian yang digunakan adalah:

\subsection{Teknik Pengumpula Data a) Observasi}

Observasi atau pengamatan secara langsung yaitu teknik pengumpulan data melalui pengamatan secara langsung pada obyek penelitian. Observasi yang dilakukan pada penelitian ini adalah pada Apotek Sekar Adi. Teknik observasi bertujuan untuk mengamati keadaan di suatu tempat dan sekaligus melakukan pengumpulan data serta mengamati keseluruhan secara langsung.

\section{b) Wawancara}

Proses memperoleh keterangan untuk tujuan penelitian dengan cara tanya jawab dan berkomunikasi secara langsung dengan nara sumber apoteker. 


\subsection{Hipotesa}

H0: Tidak terdapat pengaruh positif dengan menggunakan Algoritma Apriori pada perilaku konsumen dalam melakukan transaksi pola pembelian obat. H1: Terdapat pengaruh positif dengan menggunakan Algoritma Apriori pada perilaku konsumen dalam melakukan transaksi pola pembelian obat.

\subsection{Tahap Penelitian}

Tahapan yang dilakukan dalam penelitian ini digambarkan dalam bagan sebagai berikut:

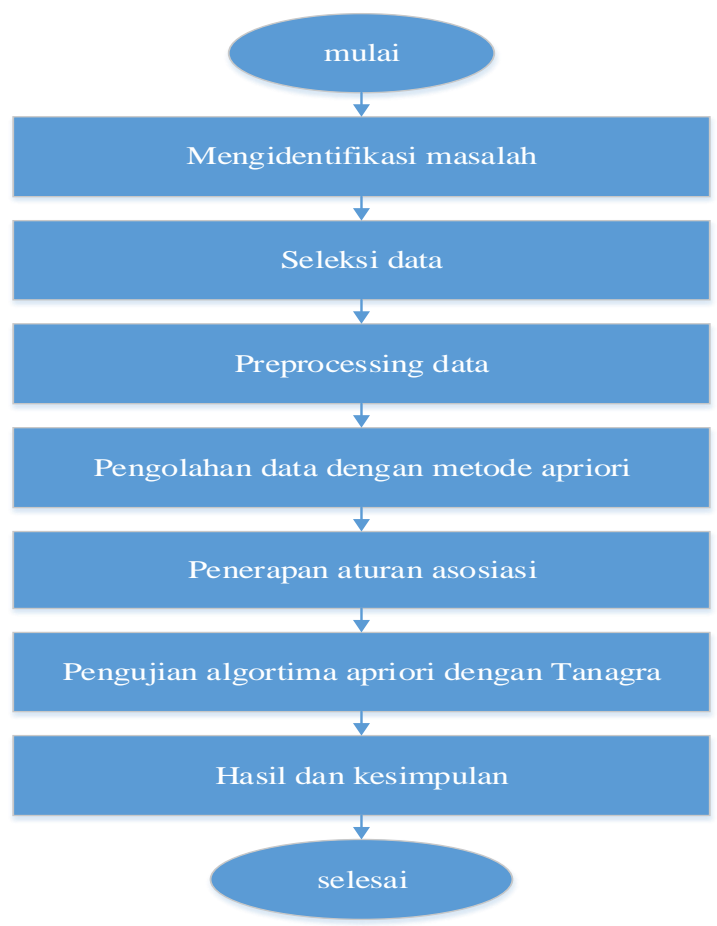

Gambar 1. Tahapan Dalam Penelitian

Analisis Asosiasi dikenal juga sebagai salah satu teknik data mining yang menjadi dasar dari berbagai teknik data mining lainnya. Khususnya salah satu tahap dari analisis asosiasi yang disebut analisis pola frequensi tinggi (frequent pattern mining) menarik perhatian banyak peneliti untuk menghasilkan algoritma yang efisien [5]. Penting tidaknya suatu aturan asosiatif dapat diketahui dengan dua parameter, yaitu support dan confidence. Support (nilai penunjang) adalah persentase kombinasi item tersebut dalam database, sedangkan confidence (nilai kepastian) adalah kuatnya hubungan antar item dalam aturan asosiasi [3].

\section{HASIL DAN PEMBAHASAN}

\subsection{Populasi}

Populasi dalam penelitian ini adalah data penjualan obat yang ada di Apotek Sekar Adi dari bulan Juli sampai dengan Desember 2018 dengan jumlah 102 data obat bebas. 


\subsection{Sampel}

Dalam penelitian ini golongan obat yang akan dibahas adalah Obat Bebas dengan jumlah sampel 40 data obat bebas.

\subsection{Pembahasan}

\subsubsection{Daftar Obat Bebas}

Berikut data obat bebas dari bulan Juli, Agustus, September, Oktober, November, dan Desember 2018 yang sudah melalui beberapa tahapan Knowledge Discovery Database (KDD) dengan jumlah 10 data obat bebas yaitu:

Tabel 1. Data Obat Bebas 2018

\begin{tabular}{|c|l|}
\hline No & \multicolumn{1}{|c|}{ Nama Obat } \\
\hline 1 & MOLAGIT PER TAB \\
\hline 2 & MICROLAX \\
\hline 3 & PANADOL (BIRU) \\
\hline 4 & TERMOREX SYR \\
\hline 5 & VIT A IPI \\
\hline 6 & SANGOBION KAPSUL \\
\hline 7 & MYLANTA \\
\hline 8 & VIT C TABLET \\
\hline 9 & PARACETAMOL 500 MG TABLET \\
\hline 10 & CALLUSOL \\
\hline
\end{tabular}

\subsubsection{Pembentukan Kode Data Obat Bebas}

Dengan membuat pengkodean data obat bebas untuk mempermudah pembuatan tabel tabulasi pada tahap selanjutnya, dapat dilihat pada table berikut ini:

Tabel 2. Pengkodean Obat Bebas

\begin{tabular}{|c|l|c|}
\hline No & \multicolumn{1}{|c|}{ Nama Obat } & Kode \\
\hline 1 & MOLAGIT PER TAB & M1 \\
\hline 2 & MICROLAX & M2 \\
\hline 3 & PANADOL (BIRU) & P1 \\
\hline 4 & TERMOREX SYR & T1 \\
\hline 5 & VIT A IPI & V1 \\
\hline 6 & SANGOBION KAPSUL & $\mathrm{S} 1$ \\
\hline 7 & MYLANTA & $\mathrm{M} 3$ \\
\hline 8 & VIT C TABLET & $\mathrm{V} 2$ \\
\hline 9 & PARACETAMOL 500 MG TABLET & $\mathrm{P} 2$ \\
\hline 10 & CALLUSOL & $\mathrm{C} 1$ \\
\hline
\end{tabular}

\subsubsection{Tabulasi Data Penjualan Obat Bebas}

Pada data transaksi penjualan obat dibentuk tabel tabular yang akan mempermudah dalam mengetahui berapa banyak item yang ada dibeli dalam setiap transaksi dapat dilihat pada table berikut ini:

Tabel 4. Tabulasi Data Penjualan Obat Bebas

\begin{tabular}{|l|l|l|l|l|l|l|l|l|l|l|}
\hline Transaksi Bulan Ke- & M1 & M2 & P1 & T1 & V1 & S1 & M3 & V2 & P2 & C1 \\
\hline 1 & 0 & 0 & 1 & 0 & 0 & 0 & 1 & 0 & 1 & 1 \\
\hline
\end{tabular}




\begin{tabular}{|l|l|l|l|l|l|l|l|l|l|l|}
\hline Transaksi Bulan Ke- & M1 & M2 & P1 & T1 & V1 & S1 & M3 & V2 & P2 & C1 \\
\hline 2 & 1 & 1 & 0 & 0 & 0 & 0 & 0 & 1 & 1 & 0 \\
\hline 3 & 0 & 0 & 1 & 0 & 0 & 0 & 0 & 1 & 1 & 0 \\
\hline 4 & 0 & 0 & 0 & 1 & 1 & 0 & 1 & 0 & 1 & 0 \\
\hline 5 & 0 & 1 & 0 & 0 & 0 & 0 & 0 & 0 & 1 & 0 \\
\hline 6 & 1 & 0 & 0 & 0 & 0 & 1 & 0 & 1 & 1 & 0 \\
\hline Jumlah & 2 & 2 & 2 & 1 & 1 & 1 & 1 & 3 & 6 & 1 \\
\hline
\end{tabular}

Sumber: Hasil Penelitian (2019)

\subsection{Analisis Pola Frekuensi Tinggi}

\subsubsection{Pembentukan Pola Kombinasi Satu Itemset}

Proses pembentukan $\mathrm{C} 1$ atau disebut dengan 1 itemset dengan jumlah minimum support $=30 \%$ Dengan rumus sebagai berikut:

$$
\text { Support }=(A)=\frac{\sum \text { Transaksi yang mengandung } A}{\sum \text { Transaksi }} * 100 \%
$$

Berikut merupakan perhitungan pembentukan 1 itemset:

1. MOLAGIT PER TAB (M1)

$$
=\frac{\sum M 1}{6}=\frac{2}{6} * 100 \%=33,33 \%
$$

2. MICROLAX, (M2)

$=\frac{\sum M 2}{6}=\frac{2}{6} * 100 \%=33,33 \%$

3. PANADOL (BIRU), (P1)

$=\frac{\sum P_{1}}{6}=\frac{2}{6} * 100 \%=33,33 \%$

4. TERMOREX SYR, (T1)

$=\frac{T 1}{6}=\frac{1}{6}=100 \%=16,67 \%$

5. VIT A IPI, (V1)

$$
=\frac{\sum V 1}{6}=\frac{1}{6}=100 \%=16,67 \%
$$

6. SANGOBION KAPSUL, (S1)

$$
=\frac{\sum S 1}{6}=\frac{1}{6} * 100 \%=16,67 \%
$$

7. MYLANTA, (M3)

$$
=\frac{\sum M 3}{6}=\frac{2}{6} * 100 \%=33,33 \%
$$

8. VIT C TABLET, (V2)

$$
=\frac{\sum V 2}{6}=\frac{3}{6} * 100 \%=50 \%
$$

9. PARACETAMOL $500 \mathrm{MG}$, (P2)

10. CALLUSOL, (C1)

$$
\begin{aligned}
& =\frac{\sum p 2}{6}=\frac{6}{6} * 100 \%=100 \% \\
& =\frac{\sum C 1}{6}=\frac{1}{6} * 100 \%=16,67 \%
\end{aligned}
$$

Hasil perhitungan 1 Itemset dapat dilihat pada table berikut:

Tabel 5. Daftar Support Dari Setiap Item

\begin{tabular}{|c|l|c|c|}
\hline No & Nama Item & Jumlah & Support \\
\hline $\mathbf{1}$ & M1 & $\mathbf{2}$ & $\mathbf{3 3 , 3 3 \%}$ \\
\hline $\mathbf{2}$ & M2 & $\mathbf{2}$ & $\mathbf{3 3 , 3 3 \%}$ \\
\hline $\mathbf{3}$ & P1 & $\mathbf{2}$ & $\mathbf{3 3 , 3 3 \%}$ \\
\hline 4 & T1 & 1 & $16,67 \%$ \\
\hline 5 & V1 & 1 & $16,67 \%$ \\
\hline 6 & S1 & 1 & $16,67 \%$ \\
\hline $\mathbf{7}$ & M3 & $\mathbf{2}$ & $\mathbf{3 3 , 3 3 \%}$ \\
\hline $\mathbf{8}$ & V2 & $\mathbf{3}$ & $\mathbf{5 0 \%}$ \\
\hline $\mathbf{9}$ & P2 & $\mathbf{6}$ & $\mathbf{1 0 0 \%}$ \\
\hline 10 & C1 & 1 & $16,67 \%$ \\
\hline
\end{tabular}


Setelah melakukan perhitungan 1 itemset dan memilih itemset yang telah memenuhi minimum support maka dapat dilihat pada table berikut ini:

Tabel 6. Daftar Obat Bebas 1 Itemset Dengan Support Yang Telah Ditentukan

\begin{tabular}{|c|l|c|c|}
\hline No & Nama Item & Jumlah & Support \\
\hline 1 & M1 & 2 & $33,33 \%$ \\
\hline 2 & M2 & 2 & $33,33 \%$ \\
\hline 3 & P1 & 2 & $33,33 \%$ \\
\hline 4 & M3 & 2 & $33,33 \%$ \\
\hline 5 & V2 & 3 & $50 \%$ \\
\hline 6 & P2 & 6 & $100 \%$ \\
\hline
\end{tabular}

\subsubsection{Pembentukan Pola Kombinasi Dua Itemset}

Proses pembentukan C2 atau disebut dengan 2 itemset dengan jumlah minimum support $=30 \%$ Dengan rumus sebagai berikut:

$$
\text { Support }=(A \cap B)=\frac{\sum \text { Transaksi yang mengandung } A \text { dan } B}{\sum \text { Transaksi }} * 100 \%
$$

Berikut merupakan beberapa perhitungan pembentukan 2 itemset:

1. MOLAGIT PER TAB (M1), MICROLAX (M2)

$$
=\frac{\sum \text { Transaksi yang mengandung } A \text { dan } B}{6}=\frac{1}{6}=100 \%=16,67 \%
$$

2. MOLAGIT PER TAB (M1), PANADOL(BIRU) (P1)

$$
=\frac{\sum \text { Transaksi yang mengandung } A \text { dan } B}{6}=\frac{0}{6} * 100 \%=0 \%
$$

3. MOLAGIT PER TAB (M1), TERMOREX SYR (T1)

$$
=\frac{\sum \text { Transaksi yang mengandung } A \text { dan } B}{6}=\frac{0}{6} * 100 \%=0 \%
$$

4. MOLAGIT PER TAB (M1), VIT A IPI (V1)

$=\frac{\sum \text { Transaksi yang mengandung } A \text { dan } B}{6}=\frac{0}{6} * 100 \%=0 \%$

5. MOLAGIT PER TAB (M1), SANGOBION KAPSUL (S1)

$$
=\frac{\sum \text { Transaksi yang mengandung } A \text { dan } B}{6}=\frac{1}{6} * 100 \%=16,67 \%
$$

6. MOLAGIT PER TAB (M1), MYLANTA (M3)

$$
=\frac{\sum \text { Transaksi yang mengandung } A \text { dan } B}{6}=\frac{0}{6} * 100 \%=0 \%
$$

7. MOLAGIT PER TAB (M1), VIT C TABLET (V2)

$$
=\frac{\sum \text { Transaksi yang mengandung } A \text { dan } B}{6}=\frac{2}{6} * 100 \%=33,33 \%
$$

Setelah melakukan perhitungan 2 itemset dan memilih itemset yang telah memenuhi minimum support maka dapat dilihat pada table berikut ini:

Tabel 7. Daftar Obat Bebas 2 Itemset Dengan Support Yang Telah Ditentukan

\begin{tabular}{|c|c|c|c|}
\hline No & Itemset & Jumlah & Support \\
\hline 1 & $\mathrm{M} 1, \mathrm{~V} 2$ & 2 & 33,33 \\
\hline 2 & $\mathrm{M} 1, \mathrm{P} 2$ & 2 & 33,33 \\
\hline 3 & $\mathrm{M} 2, \mathrm{P} 2$ & 2 & 33,33 \\
\hline 4 & $\mathrm{P} 1, \mathrm{P} 2$ & 2 & 33,33 \\
\hline 5 & $\mathrm{M} 3, \mathrm{P} 2$ & 2 & 33,33 \\
\hline 6 & $\mathrm{~V} 2, \mathrm{P} 2$ & 3 & $50 \%$ \\
\hline
\end{tabular}




\subsubsection{Pembentukan Pola Kombinasi Tiga Itemset}

Proses pembentukan C3 atau disebut dengan 3 itemset dengan jumlah minimum support $=30 \%$ Dengan rumus sebagai berikut:

$$
\text { Support }=(A \cap B \cap C)=\frac{\sum \text { Transaksi yang mengandung } A_{\sharp} B \text { dan } C}{\sum \text { Transaksi }} * 100 \%(3)
$$

Berikut merupakan beberapa perhitungan pembentukan 3 itemset:

1. MOLAGIT PER TAB (M1), MICROLAX (M2), PANADOL(BIRU) (P1)

$$
=\frac{\sum \text { Transaksi yang mengandung } A_{t} B \text { dan } C}{6}=\frac{0}{6} * 100 \%=0 \%
$$

2. MOLAGIT PER TAB (M1), MICROLAX (M2), TERMOREX SYR (T1)

$$
=\frac{\sum \text { Transaksi yang mengandung } A_{2} B \text { dan } C}{6}=\frac{0}{6} * 100 \%=0 \%
$$

3. MOLAGIT PER TAB (M1), MICROLAX (M2), VIT A IPI (V1)

$$
=\frac{\sum \text { Transaksi yang mengandung } A_{2} B \text { dan } C}{6}=\frac{0}{6} * 100 \%=0 \%
$$

4. MOLAGIT PER TAB (M1), MICROLAX (M2), SANGOBION KAPSUL (S1)

$$
=\frac{\sum \text { Transaksi yang mengandung } A_{a} B \text { dan } C}{6}=\frac{0}{6} \cdot 100 \%=0 \%
$$

5. MOLAGIT PER TAB (M1), MICROLAX (M2), MYLANTA (M3)

$$
=\frac{\sum \text { Transaksi yang mengandung } A_{l} B \text { dan } C}{6}=\frac{0}{6} * 100 \%=0 \%
$$

6. MOLAGIT PER TAB (M1), MICROLAX (M2), VIT C TABLET (V2)

$=\frac{\sum \text { Transaksi yang mengandung } A_{l} B \text { dan } C}{6}=\frac{1}{6}=100 \%=16,67 \%$

7. MOLAGIT PER TAB (M1), MICROLAX (M2), PARACETAMOL 500 MG TABLET (P2)

$=\frac{\sum \text { Transaksi yang mengandung } A_{2} B \text { dan } C}{6}=\frac{1}{6} * 100 \%=16,67 \%$

Setelah melakukan perhitungan 3 itemset dan memilih itemset yang telah memenuhi minimum support maka dapat dilihat pada table berikut ini:

Tabel 8. Daftar Obat Bebas 3 Itemset Dengan Support Yang Telah Ditentukan

\begin{tabular}{|r|l|c|c|}
\hline No & Itemset & Jumlah & Support \\
\hline 1 & M1,V2,P2 & 2 & 33,33 \\
\hline
\end{tabular}

Karena kombinasi 4 itemset tidak ada yang memenuhi minimal support $30 \%$, maka kombinasi 3 itemset yang memenuhi untuk pembentukan asosiasi dan pencarian nilai support dihentikan.

\subsubsection{Pembentukan Aturan Asosiasi}

Setelah semua pola frekuensi tinggi ditemukan, barulah dicari aturan asosiasi yang memenuhi syarat minimum untuk confidence dengan menghitung confidence aturan asosiatif $\mathrm{A}, \mathrm{B} \rightarrow \mathrm{C}$

Dengan minimum confidence $=65 \%$ menggunakan rumus berikut:

$$
\text { Confidence }=\frac{\sum \text { Transaksi yang mengandung } A_{2} B_{d} \text { dan } C}{\sum \text { Transaksi mengandung } A \text { dan } B} \cdot 100 \%
$$

Berikut merupakan beberapa perhitungan Confidence: 
1. MOLAGIT PER TAB (M1), VIT C TABLET (V2), PARACETAMOL 500 MG TABLET (P2)

$$
=\frac{\sum \text { Transaksi yang mengandung } A_{B} B_{\text {id }} \text { dan } C}{2}=\frac{2}{2} * 100 \%=100 \%
$$

2. MOLAGIT PER TAB (M1), PARACETAMOL 500 MG TABLET (P2) VIT C TABLET (V2)

$$
=\frac{\sum \text { Transaksi yang mengandung } A_{2} B_{t} \text { dan } C}{2}=\frac{2}{2} * 100 \%=100 \%
$$

3. VIT C TABLET (V2), PARACETAMOL 500 MG TABLET (P2) MOLAGIT PER TAB (M1)

$$
=\frac{\sum \text { Transaksi yang mengandung } A_{i} B_{d} \text { dan } C}{3}=\frac{2}{3} * 100 \%=100 \%
$$

Hasil perhitungan confidence dapat dilihat pada table berikut:

Tabel 9. Hasil Aturan Asosiasi

\begin{tabular}{|c|l|c|c|}
\hline No & \multicolumn{1}{|c|}{ Itemset } & \multicolumn{1}{|c|}{ Confidence } \\
\hline 1 & $\begin{array}{l}\text { Jika membeli MOLAGIT PER TAB (M1), VIT C TABLET (V2), } \\
\text { maka akan membeli PARACETAMOL 500 MG TABLET (P2) }\end{array}$ & $2 / 2$ & $100 \%$ \\
\hline 2 & $\begin{array}{l}\text { Jika membeli MOLAGIT PER TAB (M1), PARACETAMOL 500 } \\
\text { MG TABLET (P2), maka akan membeli VIT C TABLET (V2) }\end{array}$ & $2 / 2$ & $100 \%$ \\
\hline 3 & $\begin{array}{l}\text { Jika membeli VIT C TABLET (V2), PARACETAMOL 500 MG } \\
\text { TABLET (P2) maka akan membeli MOLAGIT PER TAB (M1) }\end{array}$ & $2 / 3$ & $66.67 \%$ \\
\hline 4 & $\begin{array}{l}\text { Jika membeli VIT C TABLET (V2) } \\
\text { MOLAGIT PER TAB (M1), } \\
\text { maka akan membeli PARACETAMOL 500 MG TABLET (P2) }\end{array}$ & $2 / 3$ & $66,67 \%$ \\
\hline 5 & $\begin{array}{l}\text { Jika membeli PARACETAMOL 500 MG TABLET (P2) } \\
\text { VIT C TABLET (V2), maka akan membeli MOLAGIT PER } \\
\text { TAB (M1) }\end{array}$ & $2 / 3$ & $66,67 \%$ \\
\hline 6 & $\begin{array}{l}\text { Jika membeli PARACETAMOL 500 MG TABLET (P2) } \\
\text { MOLAGIT PER TAB (M1), maka akan membeli VIT C } \\
\text { TABLET (V2) }\end{array}$ & $2 / 2$ & $100 \%$ \\
\hline
\end{tabular}

Dapat dilihat dari tabel 9. bahwa semua aturan asosiasi memenuhi syarat batas minimum confidence yaitu $65 \%$ maka didapat:

a) Jika membeli MOLAGIT PER TAB (M1), VIT C TABLET (V2), maka akan membeli PARACETAMOL 500 MG TABLET (P2)

b) Jika membeli MOLAGIT PER TAB (M1), PARACETAMOL 500 MG TABLET (P2), maka akan membeli VIT C TABLET (V2)

c) Jika membeli VIT C TABLET (V2), PARACETAMOL 500 MG TABLET (P2) maka akan membeli MOLAGIT PER TAB (M1)

d) Jika membeli VIT C TABLET (V2), MOLAGIT PER TAB (M1), maka akan membeli PARACETAMOL 500 MG TABLET (P2)

e) Jika membeli PARACETAMOL 500 MG TABLET (P2), VIT C TABLET (V2), maka akan membeli MOLAGIT PER TAB (M1)

f) Jika membeli PARACETAMOL 500 MG TABLET (P2), MOLAGIT PER TAB (M1), maka akan membeli VIT C TABLET (V2) 


\subsection{Aturan Asosiasi Final}

Aturan asosiasi final berdasarkan minimal support dan minimal confidence yang telah ditentukan, dapat dilihat pada table dibawah ini:

Tabel 10. Hasil Aturan Asosiasi Final

\begin{tabular}{|r|l|c|c|}
\hline No & \multicolumn{1}{|c|}{ Itemset } & Support & Confidence \\
\hline 1 & $\begin{array}{l}\text { Jika membeli MOLAGIT PER TAB (M1), VIT C } \\
\text { TABLET (V2), maka akan membeli } \\
\text { PARACETAMOL 500 MG TABLET (P2) }\end{array}$ & $33,33 \%$ & $100 \%$ \\
\hline 2 & $\begin{array}{l}\text { Jika membeli MOLAGIT PER TAB (M1), } \\
\text { PARACETAMOL 500 MG TABLET (P2), maka } \\
\text { akan membeli VIT C TABLET (V2) }\end{array}$ & $33,33 \%$ & $100 \%$ \\
\hline 3 & $\begin{array}{l}\text { Jika membeli VIT C TABLET (V2), } \\
\text { PARACETAMOL 500 MG TABLET (P2) maka akan } \\
\text { membeli MOLAGIT PER TAB (M1) }\end{array}$ & $33,33 \%$ & $66.67 \%$ \\
\hline 4 & $\begin{array}{l}\text { Jika membeli VIT C TABLET (V2) } \\
\text { MOLAGIT PER TAB (M1), } \\
\text { maka akan membeli PARACETAMOL 500 MG } \\
\text { TABLET (P2) }\end{array}$ & $33,33 \%$ & $66,67 \%$ \\
\hline 5 & $\begin{array}{l}\text { Jika membeli PARACETAMOL 500 MG TABLET } \\
\text { (P2) } \\
\text { VIT C TABLET (V2), maka akan membeli } \\
\text { MOLAGIT PER TAB (M1) }\end{array}$ & $33,33 \%$ & $66,67 \%$ \\
\hline 6 & $\begin{array}{l}\text { Jika membeli PARACETAMOL 500 MG TABLET } \\
\text { (P2) } \\
\text { MOLAGIT PER TAB (M1), maka akan membeli } \\
\text { VIT C TABLET (V2) }\end{array}$ & $33,33 \%$ & $100 \%$ \\
\hline
\end{tabular}

Berdasarkan hasil perhitungan minimal support dan minimal confidence maka dapat disimpulkan rule kombinasi pola pembelian obat sebagai berikut:

a) MOLAGIT PER TAB (M1), VIT C TABLET (V2), PARACETAMOL 500 MG TABLET (P2) dengan nilai support 33,33\% dan nilai confidence $100 \%$, aturan tersebut berarti "100\%" dari penjualan obat bebas yang memuat item MOLAGIT PER TAB (M1), VIT C TABLET (V2) juga akan membeli PARACETAMOL 500 MG TABLET (P2), sedangkan nilai support 33,33\% dari seluruh penjualan obat bebas yang memuat ketiga item tersebut.

b) MOLAGIT PER TAB (M1), PARACETAMOL 500 MG TABLET (P2), VIT C TABLET (V2) dengan nilai support 33,33\% dan nilai confidence $100 \%$, aturan tersebut berarti "100\%" dari penjualan obat bebas yang memuat item MOLAGIT PER TAB (M1), PARACETAMOL 500 MG TABLET (P2) juga akan membeli VIT C TABLET (V2), sedangkan nilai support 33,33\% dari seluruh penjualan obat bebas yang memuat ketiga item tersebut.

c) VIT C TABLET (V2), PARACETAMOL 500 MG TABLET (P2), MOLAGIT PER TAB (M1) dengan nilai support 33,33\% dan nilai confidence $66,67 \%$, aturan tersebut berarti "66,67\%" dari penjualan obat bebas 
yang memuat item VIT C TABLET (V2), PARACETAMOL 500 MG TABLET (P2) juga akan membeli MOLAGIT PER TAB (M1), sedangkan nilai support $33,33 \%$ dari seluruh penjualan obat bebas yang memuat ketiga item tersebut.

d) VIT C TABLET (V2), MOLAGIT PER TAB (M1), PARACETAMOL 500 MG TABLET (P2) dengan nilai support 33,33\% dan nilai confidence $66,67 \%$, aturan tersebut berarti "66,67\%" dari penjualan obat bebas yang memuat item VIT C TABLET (V2), MOLAGIT PER TAB (M1) juga akan membeli PARACETAMOL 500 MG TABLET (P2), sedangkan nilai support $33,33 \%$ dari seluruh penjualan obat bebas yang memuat ketiga item tersebut.

e) PARACETAMOL 500 MG TABLET (P2), VIT C TABLET (V2), dan MOLAGIT PER TAB (M1) dengan nilai support 33,33\% dan nilai confidence $66,67 \%$, aturan tersebut berarti "66,67\%" dari penjualan obat bebas yang memuat item PARACETAMOL 500 MG TABLET (P2), VIT C TABLET (V2), juga akan membeli MOLAGIT PER TAB (M1), sedangkan nilai support 33,33\% dari seluruh penjualan obat bebas yang memuat ketiga item tersebut.

f) PARACETAMOL 500 MG TABLET (P2), MOLAGIT PER TAB (M1), dan VIT C TABLET (V2) dengan nilai support 33,33\% dan nilai confidence $100 \%$, aturan tersebut berarti "100\%" dari penjualan obat bebas yang memuat item PARACETAMOL 500 MG TABLET (P2), MOLAGIT PER TAB (M1) juga akan membeli VIT C TABLET (V2), sedangkan nilai support $33,33 \%$ dari seluruh penjualan obat bebas yang memuat ketiga item tersebut.

\subsection{Pengujian Dengan Tanagra}

Pengujian pada Tanagra dapat terbentuk dengan langkah-langkah yang telah ditentukan, yaitu sebagai berikut:

a) Memasukan file dataset yang akan diolah pada Tanagra

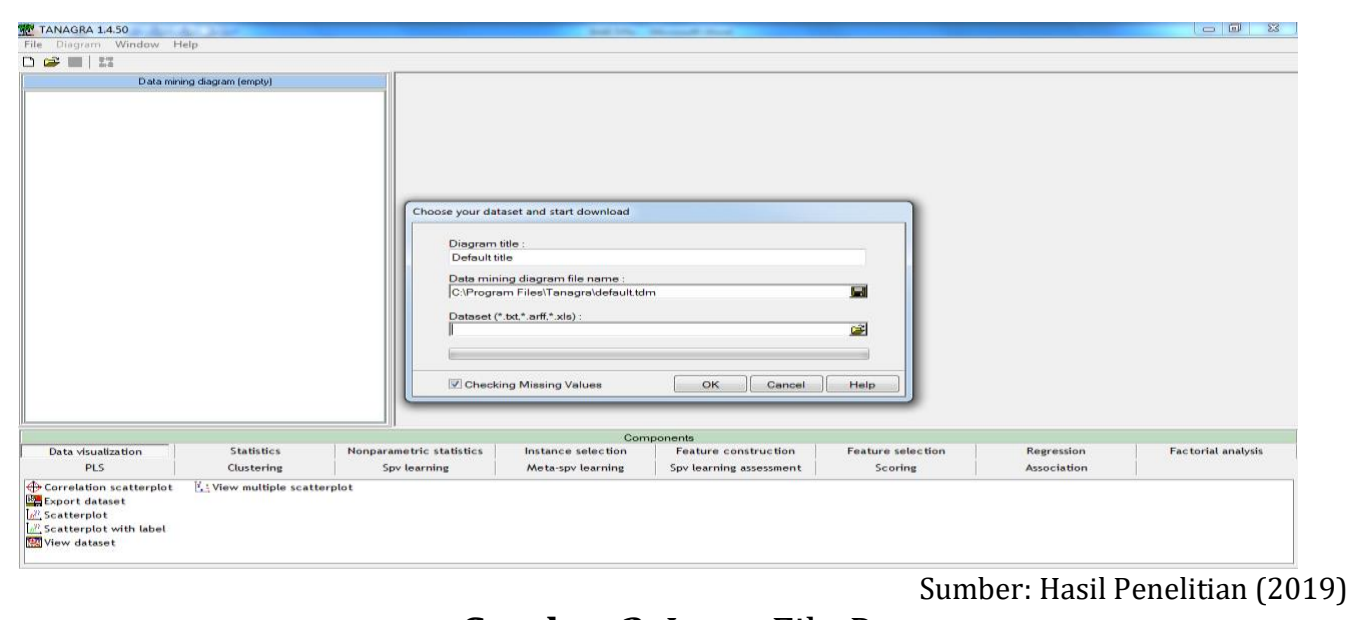

Gambar 2. Input File Dataset 
b) Pilih Data Visualization dan pilih View Dataset lalu di drop ke dataset yang sudah dimasukan diawal, klik kanan pada View Dataset lalu pilih view, maka akan tampil format tabular seperti berikut:

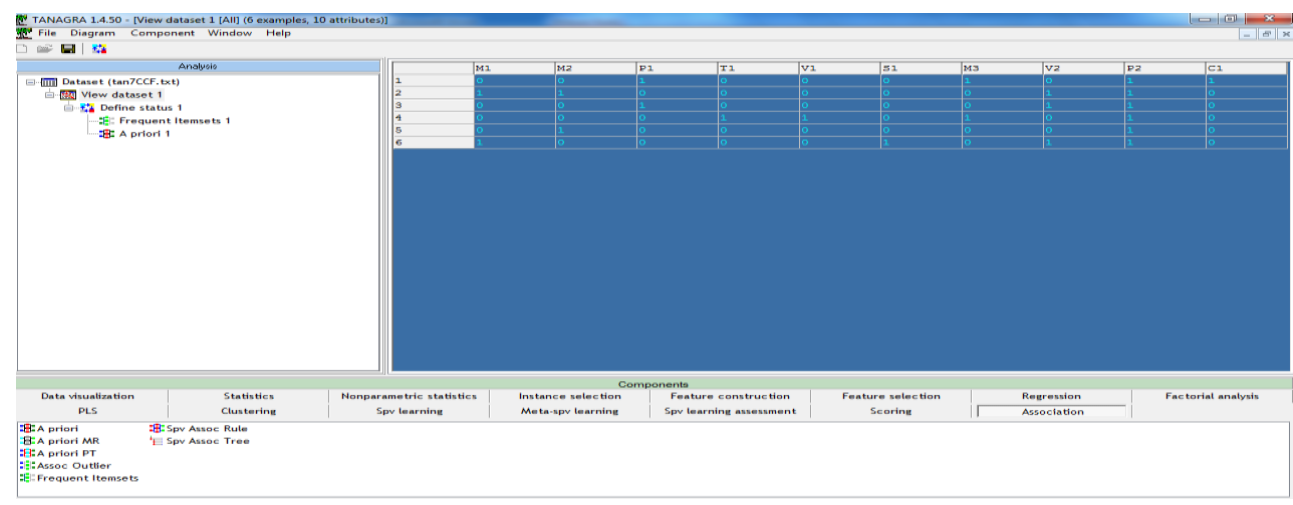

Sumber: Hasil Penelitian (2019)

Gambar 3. Tabulasi Data Obat Bebas Dengan Tanagra

c) Kemudian pilih Define Status dan pilih seluruh Attributes lalu klik Ok, maka akan tampil seperti berikut:

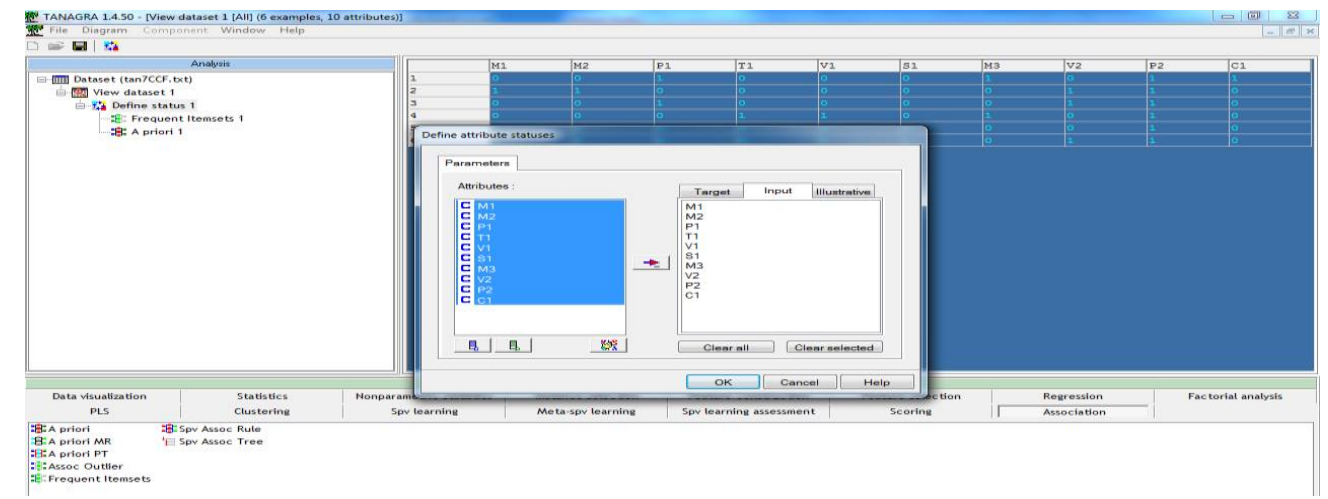

Sumber: Hasil Penelitian (2019)

Gambar 4. Pemilihan Attributes Pada Define Status

d) Selanjutnya pilih Association, klik Frequent Itemset dan drop pada Define Status, lalu klik kanan pilih parameters dan masukan Minimum Support yang telah ditentukan, maka akan tampil seperti berikut: 


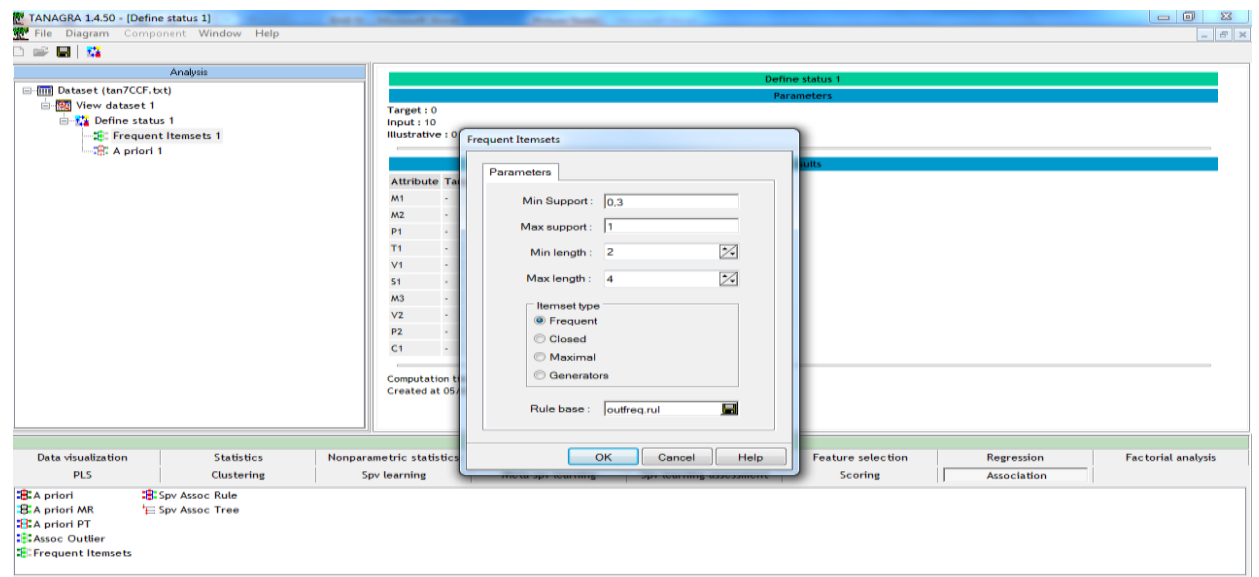

Sumber: Hasil Penelitian (2019)

Gambar 5. Tampilan Frequent Itemset

e) Klik kanan pada Frequent Itemse kemudian klik kanan pilih execute lalu klik kanan lagi pilih View, maka akan tampil seperti berikut:

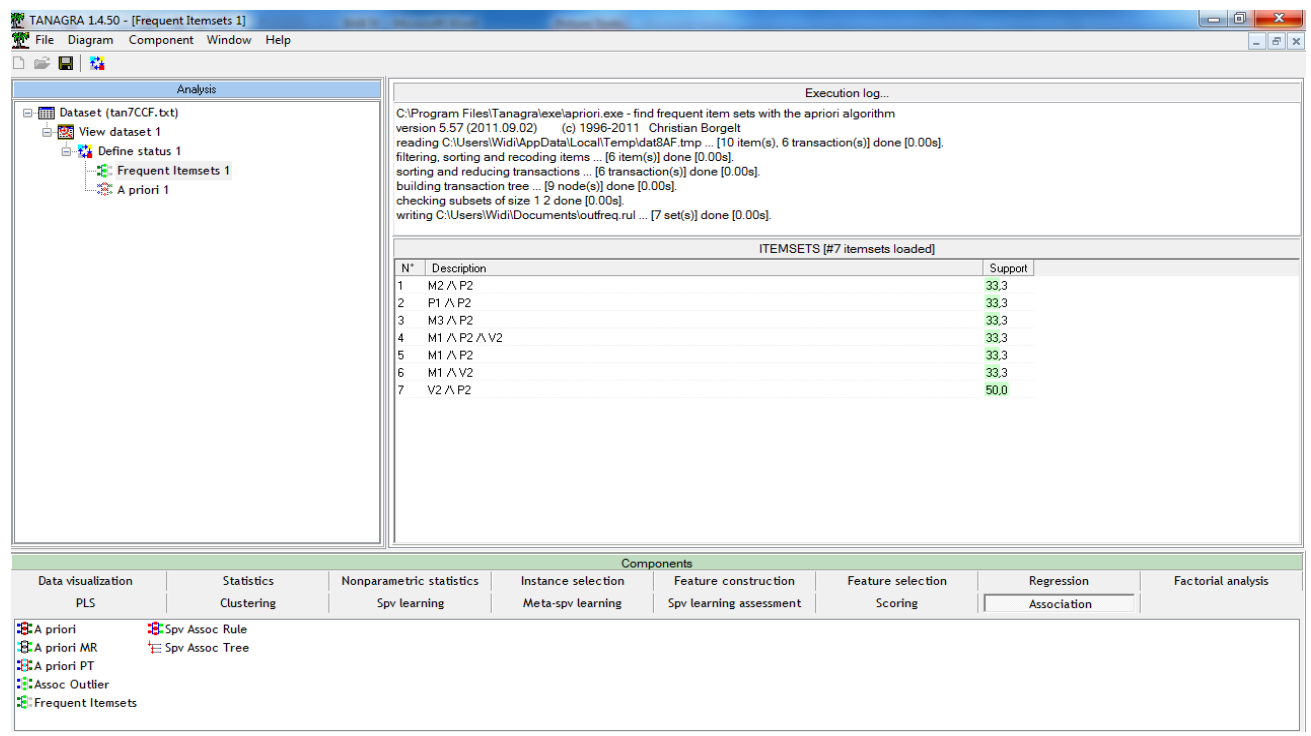

Gambar 6. Tampilan Hasil Minimum Support

f) Selanjutnya pilih Association,klik A Priori dan drop pada Define Status, lalu klik kanan pilih parameters masukan Minimum Support yang telah sudah dimasukan pada tahap sebelumnya dan masukan minimum Confidence yang sudah ditentukan, kemudian klik Ok maka akan tampil seperti berikut: 


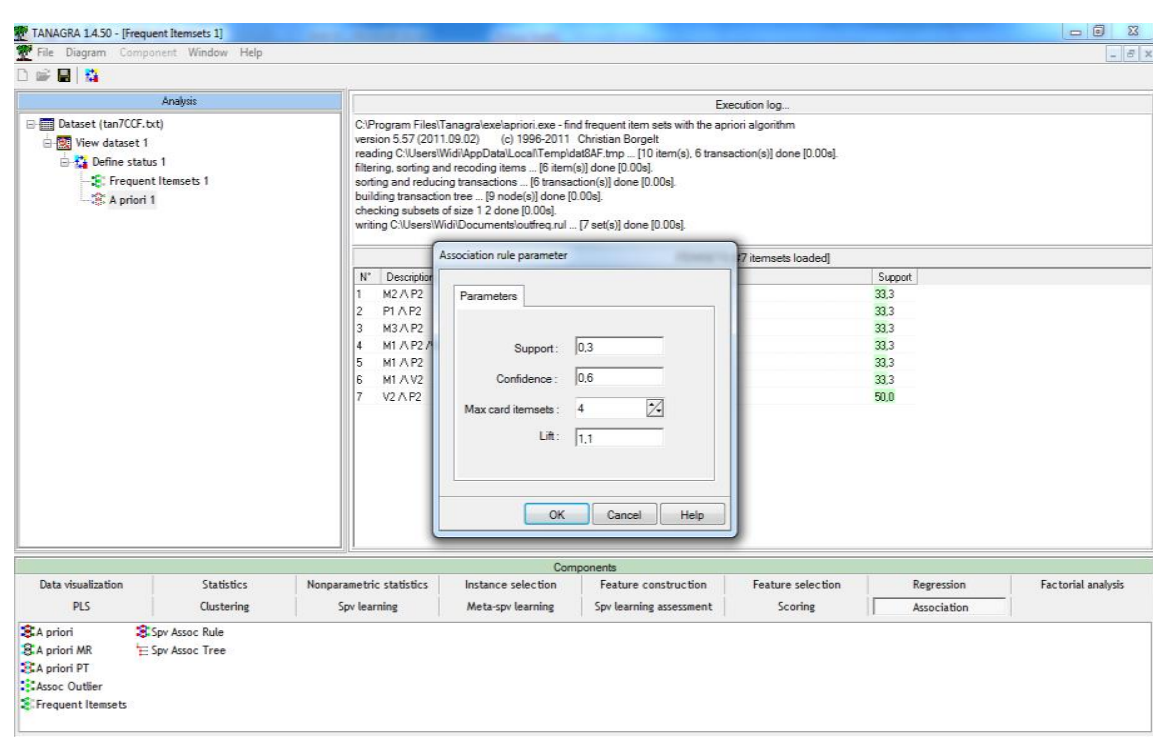

Gambar 7. Tampilan Confidence

Sumber: Hasil Penelitian (2019)

g) Klik kanan pada A Priori kemudian klik kanan pilih execute lalu klik kanan lagi pilih View, maka akan tampil seperti berikut:

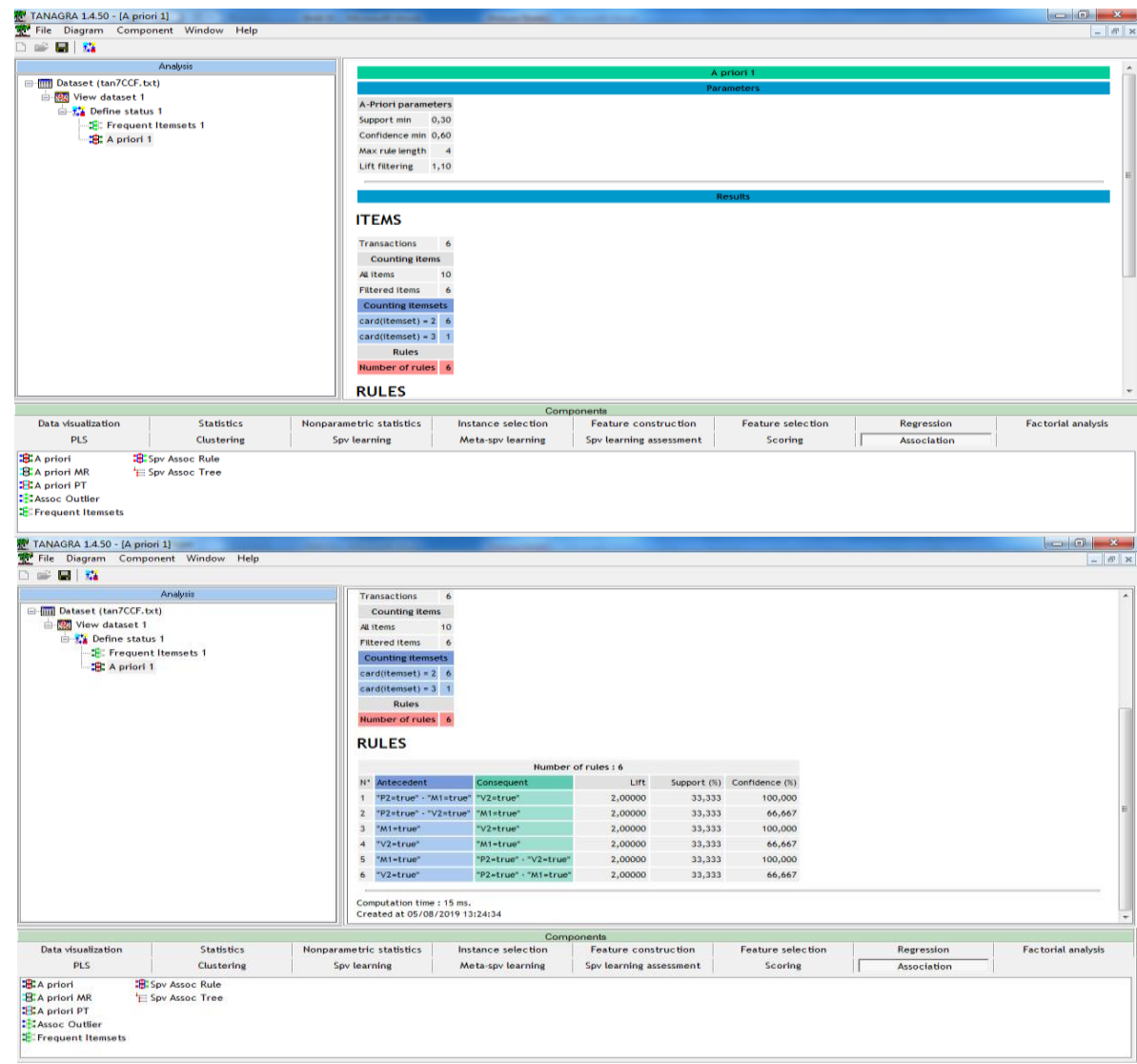

Gambar 8. Tampilan Hasil Confidence 
Dari hasil yang sudah didapat melalui perhitungan manual dengan menghitung Analisis Pola Frekuensi Tinggi dan Pembentukan Aturan Asosiasi, serta melakukan pengujian dengan tanagra hasil akhir yang didapat adalah sama. Terdapat pengaruh positif dengan menggunakan Algoritma Apriori pada perilaku konsumen dalam melakukan transaksi pola pembelian obat. Dengan minimal support 30\% terdapat kombinasi 3 itemset yaitu MOLAGIT PER TAB (M1), VIT C TABLET (V2), dan PARACETAMOL 500 MG TABLET (P2) dengan hasil support yang didapat 33,33\%, dan minimal confidence $65 \%$ terdapat 6 association rules yaitu:

1. Jika membeli MOLAGIT PER TAB (M1), VIT C TABLET (V2), maka akan membeli PARACETAMOL 500 MG TABLET (P2) dengan hasil confidence yang didapat adalah $100 \%$

2. Jika membeli MOLAGIT PER TAB (M1), PARACETAMOL 500 MG TABLET (P2), maka akan membeli VIT C TABLET (V2) dengan hasil confidence yang didapat adalah $100 \%$

3. Jika membeli VIT C TABLET (V2), PARACETAMOL 500 MG TABLET (P2) maka akan membeli MOLAGIT PER TAB (M1) dengan hasil confidence yang didapat adalah $66,67 \%$

4. Jika membeli VIT C TABLET (V2), MOLAGIT PER TAB (M1), maka akan membeli PARACETAMOL 500 MG TABLET (P2) dengan hasil confidence yang didapat adalah $66,67 \%$

5. Jika membeli PARACETAMOL 500 MG TABLET (P2), VIT C TABLET (V1), maka akan membeli MOLAGIT PER TAB (M1) dengan hasil confidence yang didapat adalah $66,67 \%$

6. Jika membeli PARACETAMOL 500 MG TABLET (P2), MOLAGIT PER TAB (M1), maka akan membeli VIT C TABLET (V2) dengan hasil confidence yang didapat adalah $100 \%$.

\section{SIMPULAN}

Beberapa kesimpulan dapat ditarik adalah

a) Proses penentuan pola pembelian obat dapat dilakukan dengan menerapkan data mining dengan metode algoritma appriori dan terdapat pengaruh positif dengan menggunakan Algoritma Apriori pada perilaku konsumen dalam melakukan transaksi pola pembelian obat, penentuan pola pembelian obat dapat dilakukan dengan melihat hasil dari kecenderungan konsumen membeli obat berdasarkan kombinasi 3 itemset. Dan juga untuk mempersiapkan persediaan obat yang dibutuhkan konsumen.

b) Hasil rules yang sudah didapat dipengaruhi oleh batasan yang sudah ditentukan, dari banyaknya data, menghitung pola frekuensi tinggi dengan minimal support $30 \%$ dan pembentukan aturan asosiasi dengan minimum confidene $65 \%$ serta hasil final association rule yang sudah dilakukan perhitungan secara manual dan pengujian menggunakan tanagra, dapat dilihat sebagai berikut: 
c) MOLAGIT PER TAB (M1), VIT C TABLET (V2), PARACETAMOL 500 MG TABLET (P2) dengan nilai support 33,33\% dan nilai confidence $100 \%$, aturan tersebut berarti "100\%" dari penjualan obat bebas yang memuat item MOLAGIT PER TAB (M1), VIT C TABLET (V2) juga akan membeli PARACETAMOL 500 MG TABLET (P2), sedangkan nilai support 33,33\% dari seluruh penjualan obat bebas yang memuat ketiga item tersebut.

d) MOLAGIT PER TAB (M1), PARACETAMOL 500 MG TABLET (P2), VIT C TABLET (V2) dengan nilai support $33,33 \%$ dan nilai confidence $100 \%$, aturan tersebut berarti "100\%" dari penjualan obat bebas yang memuat item MOLAGIT PER TAB (M1), PARACETAMOL 500 MG TABLET (P2) juga akan membeli VIT C TABLET (V2), sedangkan nilai support 33,33\% dari seluruh penjualan obat bebas yang memuat ketiga item tersebut.

e) VIT C TABLET (V2), PARACETAMOL 500 MG TABLET (P2), MOLAGIT PER TAB (M1) dengan nilai support 33,33\% dan nilai confidence $66,67 \%$, aturan tersebut berarti "66,67\%" dari penjualan obat bebas yang memuat item VIT C TABLET (V2), PARACETAMOL 500 MG TABLET (P2) juga akan membeli MOLAGIT PER TAB (M1), sedangkan nilai support $33,33 \%$ dari seluruh penjualan obat bebas yang memuat ketiga item tersebut.

f) VIT C TABLET (V2), MOLAGIT PER TAB (M1), PARACETAMOL 500 MG TABLET (P2) dengan nilai support $33,33 \%$ dan nilai confidence $66,67 \%$, aturan tersebut berarti "66,67\%" dari penjualan obat bebas yang memuat item VIT C TABLET (V2), MOLAGIT PER TAB (M1) juga akan membeli PARACETAMOL 500 MG TABLET (P2), sedangkan nilai support $33,33 \%$ dari seluruh penjualan obat bebas yang memuat ketiga item tersebut.

g) PARACETAMOL 500 MG TABLET (P2), VIT C TABLET (V2), dan MOLAGIT PER TAB (M1) dengan nilai support 33,33\% dan nilai confidence $66,67 \%$, aturan tersebut berarti "66,67\%" dari penjualan obat bebas yang memuat item PARACETAMOL 500 MG TABLET (P2), VIT C TABLET (V2), juga akan membeli MOLAGIT PER TAB (M1), sedangkan nilai support 33,33\% dari seluruh penjualan obat bebas yang memuat ketiga item tersebut.

h) PARACETAMOL 500 MG TABLET (P2), MOLAGIT PER TAB (M1), dan VIT C TABLET (V2) dengan nilai support 33,33\% dan nilai confidence $100 \%$, aturan tersebut berarti " $100 \%$ " dari penjualan obat bebas yang memuat item PARACETAMOL 500 MG TABLET (P2), MOLAGIT PER TAB (M1) juga akan membeli VIT C TABLET (V2), sedangkan nilai support $33,33 \%$ dari seluruh

\section{DAFTAR PUSTAKA}

[1] Djamaludin, I., \& Nursikuwagus, A. (2017). Analisis Pola Pembelian Konsumen Pada Transaksi Penjualan Menggunakan Algoritma Apriori. Simetris : Jurnal 
Jurnal Sains Komputer \& Informatika (J-SAKTI) Volume 4 Nomor 1 Maret 2020, pp. 112-127

ISSN: 2548-9771/EISSN: 2549-7200

http://tunasbangsa.ac.id/ejurnal/index.php/jsakti

Teknik Mesin, Elektro Dan Ilmu Komputer, 8(2), 671. Https://Doi.Org/10.24176/Simet.V8i2.1566

[2] Nofriansyah, D. (2014). Konsep Data Mining Vs Sistem Pendukung Keputusan (1 St). Deepublish.

[3] Salamah, E. N., \& Ulinnnuha, N. (2018). Analisis Pola Pembelian Obat Dan Alat Kesehatan Di Klinik Ibu Dan Anak Graha Amani Dengan Menggunakan Algoritma Apriori. Jurnal INFORM, 2(2), 1-6. Https://Doi.Org/10.25139/Ojsinf.V2i1.401

[4] Vulandari, R. T. (2017). DATA MINING Teori Dan Aplikasi Rapidminer. Gava Medika.

[5] Yanto, R., \& Khoiriah, R. (2018). Implementasi Data Mining Dengan Metode Algoritma Apriori Dalam Menentukan Pola Pembelian Obat. Creative $\begin{array}{llll}\text { Information Technology } & \text { Journal, } & \end{array}$ Https://Doi.Org/10.24076/Citec.2015v2i2.41 